\title{
Occupational asthma due to chrome and nickel electroplating
}

Philip Bright, P Sherwood Burge, Stephen P O’Hickey, Paul F G Gannon, Alastair S Robertson, Ahmed Boran
The Occupational Lung Disease Unit, Birmingham

Heartlands Hospital,

Bordesley Green East,

Birmingham B9 5ST,

UK

P Bright

P S Burge

S P O'Hickey

P F G Gannon

A S Robertson

A Boran

Correspondence to: Dr P S Burge.

Received 25 January 1995 Returned to authors

19 April 1995

Revised version received

26 June 1996

Accepted for publication

28 June 1996

\section{Abstract}

Background - Exposure to chromium during electroplating is a recognised though poorly characterised cause of occupational asthma. The first series of such patients referred to a specialist occupational lung disease clinic is reported.

Methods - The diagnosis of occupational asthma was made from a history of asthma with rest day improvement and confirmed by specific bronchial provocation testing with potassium dichromate and nickel chloride.

Results - Seven workers had been exposed to chrome and nickel fumes from electroplating for eight months to six years before asthma developed. One subject, although exposed for 11 years without symptoms, developed asthma after a single severe exposure during a ventilation failure. This was the only subject who had never smoked. The diagnosis was confirmed by specific bronchial challenges. Two workers had isolated immediate reactions, one a late asthmatic reaction, and four a dual response following exposure to nebulised potassium dichromate at $\mathbf{1 - 1 0} \mathrm{mg} / \mathrm{ml}$. Two of the four subjects were also challenged with nebulised nickel chloride at $0.1-10 \mathrm{mg} / \mathrm{ml}$. Two showed isolated late asthmatic reactions, in one at $0.1 \mathrm{mg} / \mathrm{ml}$, where nickel was probably the primary sensitising agent. Four workers carried out two hourly measurements of peak expiratory flow over days at and away from work. All were scored as having occupational asthma using OASYS-2. Breathing zone air monitoring was carried out in 60 workers from four decorative and two hard chrome plating shops from workers with similar jobs to those sensitised. No measurement exceeded the current occupational exposure standard for chromate or nickel, the mean levels of chromate exposure for jobs similar to those of the affected workers were 9-15 $\mu \mathrm{g} / \mathbf{m}^{3}$.

Conclusion - Chrome used in electroplating is a potential cause of occupational asthma. Sensitivity to chrome in electroplaters may occur in situations where exposure levels are likely to be within the current exposure standards. There may be cross reactivity with nickel. Inhalation challenge with nebulised potassium di- chromate solution is helpful in making the specific diagnosis where doubt exists. (Thorax 1997;52:28-32)

Keywords: occupational asthma, electroplating, chrome, nickel, bronchial provocation testing.

Chromium is the major industrial contact allergen that causes dermatitis ${ }^{1}$ and is widely used in electroplating, dyes, leather tanning, and cement works. Single cases of asthma caused by chrome have been described since the nineteenth century and in the 1930 s both Smith $^{2}$ and Joules $^{3}$ reported chromium induced asthma due to exposure at work. Since then there have been very few reports of respiratory symptoms in workers associated with electroplating.

Electroplating is the application of a metallic coating to articles using inorganic salts of metals such as chromium or nickel. In the electroplating process the gases released at the electrodes rise to the surface of the bath and generate a fine aerosol. Nickel electroplating is $95 \%$ efficient and gas generation is minimal whereas chromium electroplating is inefficient and $80-90 \%$ of the total energy used may be directed to the generation of potentially respirable aerosols of chromic acid. Epidemiological studies have suggested increased respiratory morbidity in electroplaters compared with galvanisers that is related to exposure to chromium. ${ }^{4}$ We report here our experience with chromium induced asthma in workers referred to a specialist occupational lung disease clinic over 10 years.

\section{Methods}

Subjects were identified at a specialist occupational lung disease clinic. The current report includes all those investigated by occupational type bronchial provocation testing over the last 10 years. The clinic has an additional six workers from the same industry who have not had challenge testing, but whose diagnosis is also likely to be occupational asthma from plating shop fumes. None were identified as part of epidemiological surveys.

SKIN TESTING

Skin prick tests were performed using a range of common environmental solutions (Bencard, UK). Atopy was defined as a weal of $2 \mathrm{~mm}$ or 
more than that caused by a diluent control solution. Skin prick tests were also performed with solutions of nickel chloride and potassium dichromate at concentrations of 1 and $10 \mathrm{mg} /$ $\mathrm{ml}$ diluted in isotonic saline.

SERIAL PEAK FLOW MEASUREMENTS

For workers still exposed at the time of referral serial readings of peak expiratory flow (PEF) were recorded two hourly from waking until sleeping using a mini-Wright peak flow meter on days at and away from work. Workers were instructed to record the best of three readings reproducible within $20 \mathrm{l} / \mathrm{min}$, and the records were subsequently analysed using the OASYS2 analysis program. ${ }^{5}$

AIRWAY CHALLENGES

Airway challenges to potassium dichromate solutions $(0.1 \mathrm{mg} / \mathrm{ml})$ were performed on an inpatient basis using a Wright nebuliser driven with air at $81 / \mathrm{min}$ by a compressor unit. On the day of challenge inhaled and oral bronchodilators were withheld but any inhaled corticosteroids were continued. After a stable baseline period subjects inhaled the test solution during tidal breathing initially for one minute. Forced expiratory volume in one second $\left(\mathrm{FEV}_{1}\right)$ was measured using a dry bellows spirometer (Vitalograph, Buckingham, UK) at 5 and 10 minutes thereafter. If the $\mathrm{FEV}_{1}$ fell by less than $10 \%$ the subject inhaled further two minute doses up to a total of five minutes. Spirometric tests were subsequently repeated every five minutes for the first 30 minutes, every 10 minutes for the next 30 minutes, at 90 minutes, and then at hourly intervals throughout the day. If no early or late response was seen the challenge was repeated on the following days with solutions at concentrations of $1 \mathrm{mg} / \mathrm{ml}$ and then $10 \mathrm{mg} / \mathrm{ml}$. Nebulised saline was used as a negative control and nickel chloride solution as a second challenge in some cases. Subjects were not aware of the challenge solution. In order to control for both the acidity and the tonicity of the solutions, a further control exposure to potassium chloride solution at $\mathrm{pH}$ 3.8 was made in one subject.

\section{AIR SAMPLING}

As part of an epidemiological survey of electroplaters in the West Midlands UK an extensive air monitoring programme was undertaken in 60 workers from the larger electroplating shops. All workers present on the days of sampling (always Thursdays) took part ( $86.5 \%$ of the total workforce). Two hour personal samples breathing zone air were collected on a $25 \mathrm{~mm}$ glass fibre membrane with a pore size of $0.8 \mu \mathrm{m}$ mounted on a closed face seven hole cassette with airflow of $21 / \mathrm{min}$. Nickel and chrome levels were measured by atomic absorption spectroscopy using the Health and Safety Executive method. ${ }^{6}$ The results for the occupational categories corresponding to the workers studied are reported.

\section{Results}

Details of the seven workers studied are shown in table 1. All came from factories where both chrome and nickel (or zinc in one case) were used for plating or passivating. Six came from factories where decorative plating was taking place, and one (subject 4) from a factory hard plating large objects. Three workers were employed as platers, working directly with the plating baths, the other four were only incidentally exposed within the same general environment.

In the first subject asthma started after an unusual acute exposure when the extraction fans on both chrome and nickel plating baths failed, filling the factory with a visible cloud of fume; he had been asymptomatic in this job for the previous 11 years. In the others there was a latent interval between first exposure and the onset of symptoms ranging from eight months to six years, with no unusual exposures before symptoms developed. Of these, all but two were current smokers and one out of six was atopic. Two of the seven subjects had a $>2 \mathrm{~mm}$ weal following prick testing with potassium dichromate $(10 \mathrm{mg} / \mathrm{ml})$ and two had positive reactions to nickel chloride $(10 \mathrm{mg} / \mathrm{ml})$.

Five workers had significant $(>20 \%$ fall from baseline) immediate asthmatic reactions following exposure to potassium dichromate at concentrations between 1 and $10 \mathrm{mg} / \mathrm{ml}$. In addition, four developed significant late asthmatic reactions. One worker had a borderline early reaction (subject 7 ) and one (subject 1) a borderline late asthmatic reaction. Challenges to nickel chloride in concentrations of $0.1-10 \mathrm{mg} / \mathrm{ml}$ were performed in five workers resulting in one borderline immediate reaction and two late asthmatic reactions. In the first subject the reaction was at $0.1 \mathrm{mg} / \mathrm{ml}$ for nickel and $10 \mathrm{mg} / \mathrm{ml}$ for chrome, suggesting that the principal sensitisation was to nickel; the others had greater reactions to chrome. The $\mathrm{pH}$ of the challenge solutions was measured for concentrations from 0.1 to $10 \mathrm{mg} / \mathrm{ml}$. Nickel chloride had a $\mathrm{pH}$ ranging from 5.25 to 5.27, whereas the $\mathrm{pH}$ of potassium dichromate decreased from 4.21 to 3.83 with increasing concentration. The last subject was challenged with potassium chloride $(10 \mathrm{mg} / \mathrm{ml})$, with $\mathrm{pH}$ adjusted to 3.83 , with negative results (fig 1 ).

Serial PEF records during exposure were available in four workers as indicated in table 2. All the PEF records had evidence of a work related effect as determined by the OASYS-2 analysis. An OASYS-2 score of more than 2.51 indicated the presence of a significant work related effect in the serial PEF record. The symptoms in subject 1 were so severe on returning to the work place that only a short period of exposure (two days) could be tolerated. The PEF record from subject 1 and part of the record from subject 4 are shown in fig 2.

The results for the personal samples breathing zone air for nickel and chromate are shown in table 3 . The results came from four plants where decorative plating took place, and two where hard plating occurred. Subject 4 worked at one of the hard plating shops where air 
Table 1 Demographic data and results of skin and specific bronchial challenge tests on seven workers with asthma due to chrome

\begin{tabular}{|c|c|c|c|c|c|c|c|c|c|c|c|c|c|}
\hline \multirow[t]{2}{*}{$\begin{array}{l}\text { Subject } \\
\text { no. }\end{array}$} & \multirow[t]{2}{*}{ Age } & \multirow[t]{2}{*}{ Sex } & \multirow[t]{2}{*}{ Occupation } & \multirow{2}{*}{$\begin{array}{l}\text { Latent } \\
\text { interval } \\
\text { (years) }\end{array}$} & \multirow[t]{2}{*}{$\begin{array}{l}\text { Smoking } \\
\text { history }\end{array}$} & \multirow[t]{2}{*}{$\begin{array}{l}F E V_{1}(\% \\
\text { predicted })\end{array}$} & \multirow[t]{2}{*}{ Atopy } & \multicolumn{2}{|l|}{ Prick tests } & \multicolumn{2}{|c|}{$\begin{array}{l}\text { Chromate challenge } \\
\text { (\% fall from baseline) }\end{array}$} & \multicolumn{2}{|c|}{$\begin{array}{l}\text { Nickel challenge } \\
\text { (\% fall from baseline) }\end{array}$} \\
\hline & & & & & & & & $\mathrm{Cr}$ & $N i$ & Immediate & Late & Immediate & Late \\
\hline $1 \mathrm{~A}$ & 34 & M & Plater & Acute & None & 96 & Yes & Negative & $4 \mathrm{~mm}$ & $22(10)$ & 14 & $0(0.1)$ & 26 \\
\hline 2 & 45 & $\mathrm{~F}$ & Assembler & 2 & Current & 67 & No & Negative & ND & $23(1)$ & 0 & ND & \\
\hline $3 \mathrm{~A}$ & 20 & $\mathrm{~F}$ & Jigger & 1 & Current & 98 & No & Negative & $2 \mathrm{~mm}$ & $53(10)$ & 0 & $0(10)$ & 0 \\
\hline $4 \mathrm{~A}$ & 58 & M & Manager & 2 & Current & 71 & Yes & Negative & Negative & $44(1)$ & 29 & $14(1)$ & 0 \\
\hline 5 & 59 & M & Plater & 6 & Ex-smoker & 61 & No & $4 \mathrm{~mm}$ & Negative & $5(1)$ & 43 & $0(1)$ & 0 \\
\hline 6 & 48 & M & Plater & 4 & Current & 54 & No & Negative & $4 \mathrm{~mm}$ & $27(10)$ & 21 & ND & \\
\hline $7 \mathrm{~A}$ & 55 & $\mathrm{~F}$ & Packer & $<1$ & Ex-smoker & 91 & No & $4 \mathrm{~mm}$ & $2 \mathrm{~mm}$ & $17(1)$ & 50 & $0(10)$ & 29 \\
\hline
\end{tabular}

$\mathrm{ND}=$ not done; $\mathrm{A}=$ peak flow record undertaken while still exposed

Figures in parentheses for challenge tests indicate the concentration of solution used in $\mathrm{mg} / \mathrm{ml}$.

monitoring took place and the other workers all came from other plating shops not studied in the epidemiological study. The results show that the plating bath operators are not necessarily the most heavily exposed, and that exposure levels are similar in those with incidental exposure. The heat from plating baths and the local exhaust extraction often removes the fume from the plating operators, resulting in higher than expected exposures away from the plating baths. No measurement of chromate or nickel exceeded the occupational exposure standard. Apart from subject 1 who was exposed to subjectively high levels of fume after a breakdown of the extraction system, the work

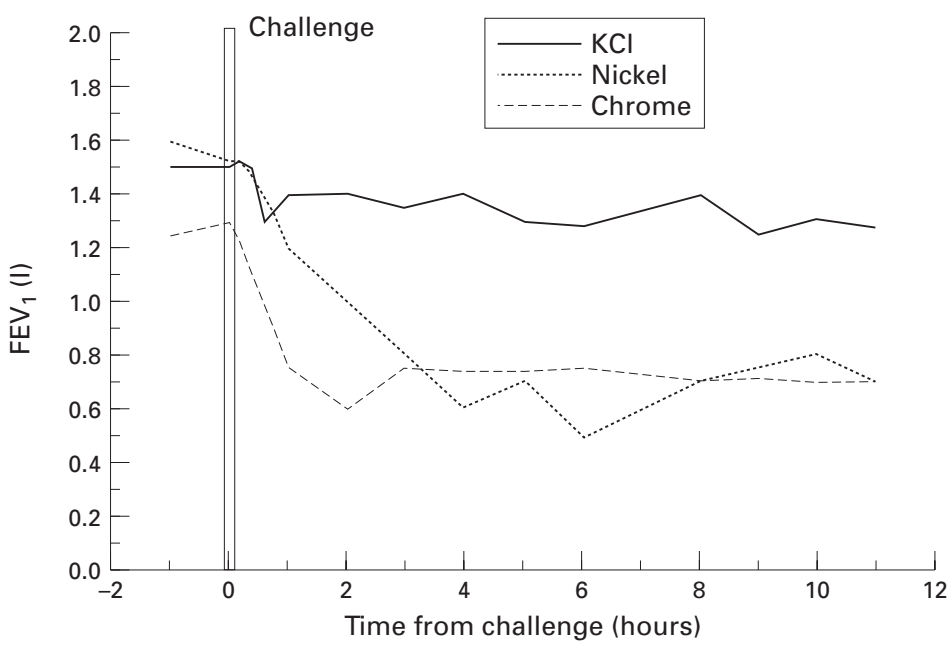

Figure 1 Bronchial provocation testing in subject 7 showing responses to nebulised acidified potassium chloride (control), potassium dichromate $1 \mathrm{mg} / \mathrm{ml}$, and nickel chloride $10 \mathrm{mg} / \mathrm{ml}$.

Table 2 Details of PEF records in subjects who recorded data while still exposed

\begin{tabular}{llllll}
\hline $\begin{array}{l}\text { Subject } \\
\text { no. }\end{array}$ & $\begin{array}{l}\text { Length } \\
\text { (days) }\end{array}$ & $\begin{array}{l}\text { Readings/ } \\
\text { day }\end{array}$ & $\begin{array}{l}\text { \% Record with diurnal } \\
\text { variation }>\text { 15\% predicted }\end{array}$ & $\begin{array}{l}\text { Mean diurnal } \\
\text { variation \% predicted }\end{array}$ & $\begin{array}{l}\text { OASYS-2 } \\
\text { scores }\end{array}$ \\
\hline 1 & 41 & 8.1 & 24.39 & 10.56 & 4.0 \\
3 & 21 & 8.19 & 14.29 & 10.28 & 2.6 \\
4 & 60 & 7.55 & 91.53 & 30.53 & 2.8 \\
7 & 28 & 6.25 & 89.66 & 25.45 & 3.83 \\
\hline
\end{tabular}

Table 3 Mean (range) air measurements at work

\begin{tabular}{lclc}
\hline & Number & $\mathrm{CrO}_{3}\left(\mu \mathrm{g} / \mathrm{m}^{3}\right)$ & $\mathrm{Ni}\left(\mu \mathrm{g} / \mathrm{m}^{3}\right)$ \\
\hline Bath operators (decorative) & 34 & $9.64(0.5-39)$ & $26.5(5-93)$ \\
Jiggers (decorative) & 22 & $14.9(0.5-50)$ & $21.2(0.5-83)$ \\
Managers (hard) & 4 & $11.5(4-19)$ & $2.6(0.5-6)$ \\
Occupational exposure standard & & 50 & 100 \\
(OES) & & & \\
\hline
\end{tabular}
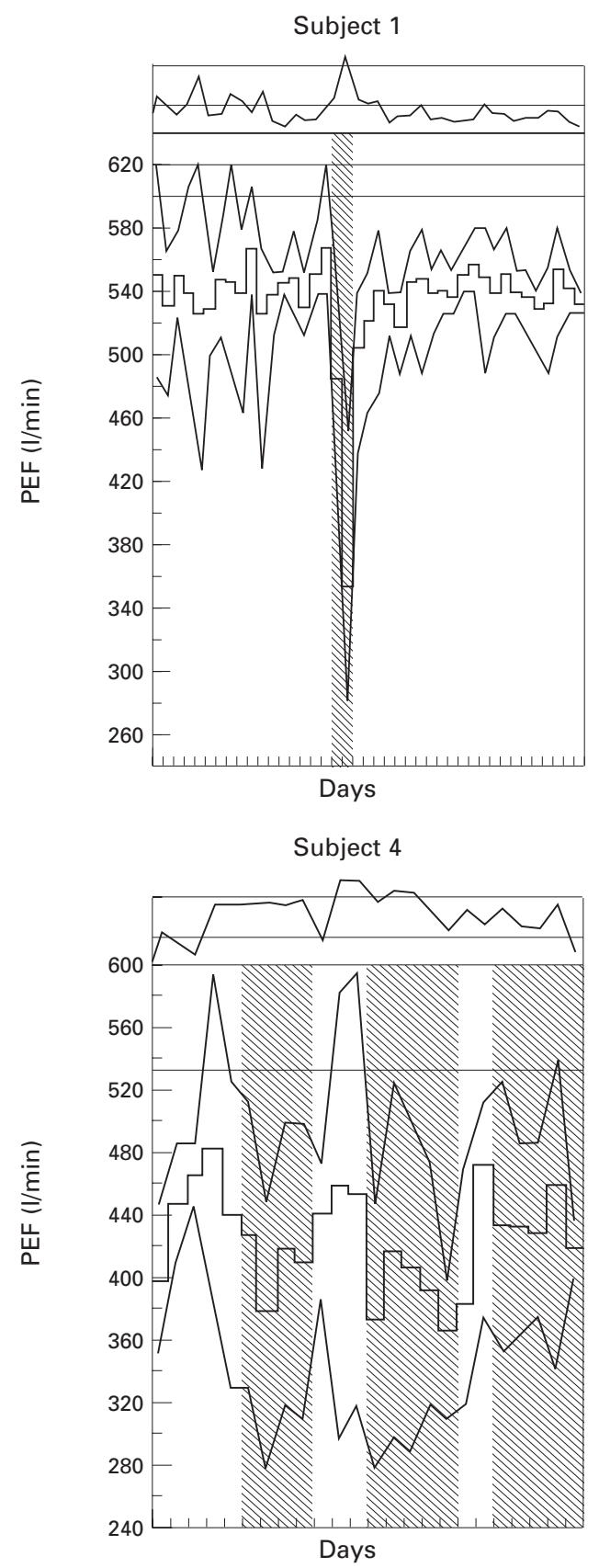

Figure 2 Plots of serial PEF records for subjects 1 and 4. Shaded areas indicate days at work, unshaded areas days away from work. Diurnal variation (\% predicted) is

illustrated at the top of each figure. The three lines in each figure represent, from top to bottom, the daily maximum, mean and minimum. 
histories of the remainder suggested that levels of exposure in the factories monitored were likely to be representative of their exposures.

\section{Discussion}

The clinical features of chrome induced asthma in seven subjects exposed in metal electroplating works are described. All had positive airway challenges to chromate solution and in two there was also a significant reaction to nickel, which was probably the primary sensitiser in the worker with the high exposure following the breakdown of an extractor fan. There was no association between atopy and skin test response to metal salts and the airways response to inhaled potassium dichromate solution. It is interesting that all those sensitised to usual electroplating shop exposures were current or ex-smokers. Cigarette smoking may enhance the absorption of chrome, perhaps due to contamination of the cigarettes or to bronchial inflammation induced by the cigarettes. Smokers are also at increased risk of developing specific IgE to some occupational allergens such as platinum salts. ${ }^{7}$

The first report of chromium induced asthma was in $1869 .{ }^{8}$ Since then there have been several reports demonstrating that bronchoconstriction can be experimentally induced either by subcutaneous injection ${ }^{39}$ or by aerosol inhalation. ${ }^{1011}$ There have only been isolated case reports of occupational asthma due to chrome exposure in electroplaters. ${ }^{3911-14}$ This is the first report of a series of such cases and the first to include air measurements from the workplace. Occupational asthma due to chromium exposure is not unique to workers in the electroplating industry. Previous reports have also demonstrated occupational asthma or bronchitis in workers welding stainless steel, ${ }^{1015}$ in concrete or construction workers, ${ }^{11}$ or chromite ore miners. ${ }^{16}$ There have also been some reports of occupational asthma in nickel platers. ${ }^{17-19}$

Specific bronchial provocation testing is generally regarded as the gold standard by which to identify the specific cause of occupational asthma. All the reported workers reacted to potassium dichromate at concentrations from 1 to $10 \mathrm{mg} / \mathrm{ml}$. Reactions can, however, be induced by irritant mechanisms if the exposures are too high. Potassium dichromate solution is acidic and it is at least possible that this contributes to the reactions seen. Previous studies of the effects of non-isotonic aerosols on airways calibre in mild asthmatics using ultrasonic nebulisers have demonstrated that the degree of hyperosmolarity, ${ }^{20}$ the ion concentration, ${ }^{21}$ the $\mathrm{pH},{ }^{21}$ and the type of ion itself $^{22}$ are all important factors in determining the airways response. It is unlikely, however, that the airway responses to challenges in this study were due simply to an irritant effect as challenge with hypertonic acidic aerosol in subject 7 did not change the airway calibre. Non-specific bronchial responsiveness was not measured routinely at the time of specific challenge, but in the only worker measured it was within the normal range. The airway challenges demonstrate the wide variety of responses to inhaled chromium salts with both single early and dual responses being seen.

The role of skin tests and RAST measurements in the diagnosis of metal induced asthma is not clear. The size of the skin reactions obtained in subjects who were clearly responsive to chrome solutions would suggest that the skin responsiveness is not a good predictor of airways response. This may suggest that metal solutions need to be presented with other proteins before becoming antigenic. Skin prick tests with potassium dichromate $(10 \mathrm{mg} /$ $\mathrm{ml})$ relate to exposure but not to asthmatic symptoms. Positive reactions ( $>2 \mathrm{~mm}$ weal) were seen in $10 \%$ of exposed workers with symptoms suggestive of occupational asthma, $15 \%$ of exposed workers with rhinitis, $11 \%$ of asymptomatic exposed workers, and $2 \%$ of unexposed controls in a cross sectional epidemiological study of plating workers. ${ }^{4}$ For workers with exposure to nickel positive reactions to a solution of $10 \mathrm{mg} / \mathrm{ml}$ were seen in $2 \%$ of workers with asthma-like symptoms, no workers with rhinitis had positive skin tests, and $9 \%$ of asymptomatic exposed workers had positive reactions; only $1 \%$ of unexposed controls had positive skin reactions to nickel. The results with serum IgE antibodies to metal salts are equally inconsistent. Novey et $a l^{14}$ demonstrated specific IgE antibodies to chromium and nickel conjugates in an electroplater who developed occupational asthma. Inhalation challenges were positive but skin tests to chromium and nickel were negative. Malo et al described a single electroplater with a positive nickel inhalation challenge in whom both skin tests and RAST were negative. ${ }^{23}$ Dolovich suggested, in a case of nickel induced asthma, that the antigenic determinant was dependent on the combination of $\mathrm{Ni}^{2+}$ with human serum albumin at the primary copper binding site. ${ }^{24}$ Similar results were reported to nickel in workers with hard metal asthma in whom cobalt is the principal allergen. ${ }^{25}$ The differences may be due in part to the ability of the metal salt to form complexes with human serum albumin.

These results suggest that airways sensitivity to chrome and nickel exists and is a significant cause of occupational asthma in electroplating workers. It is likely that, in most workers, exposure to chrome was maintained at levels below the occupational exposure limit, suggesting that still lower levels will need to be achieved to prevent sensitisation. It is important, however, to note that one worker developed his first symptoms after a single large exposure. Cross reaction with nickel may exist. Where there is doubt about the diagnosis, specific bronchial provocation testing with potassium dichromate solution may be useful.

The authors thank Ruth Cayton, Jon Ayres, and David Stableforth for referring three of the workers, and Michael Hendy for the challenges of subject 5 .

1 Peltonen L, Fraki J. Prevalence of dichromate sensitivity. Contact Dermatitis 1983;9:190-4

2 Smith AR. Chrome poisoning with manifestations of sensitisation. $\mathcal{F} A M A$ 1931;97:95-8.

3 Joules H. Asthma from sensitisation to chromium. Lancet 1932;i:182-3. 
4 Boran AM. Prevalence of occupational asthma in the electroplating industry. $\mathrm{PhD}$ Thesis, University of Birmingham, 1993.

5 Gannon PFG, Newton DT, Belcher J, Pantin CFA, Burge PS. The development of OASYS-2, a system for the analysis of measurements of peak expiratory flow in work484-9.

6 Health and Safety Executive. Chromium and inorganic compounds of chromium in air. Laboratory method using atomic absorption spectrometry.

7 Venables KM, Daily MB, Nunn AJ, et al. Smoking and occupational allergy in workers in a platinum refinery. BMF 1989;299:939-42.

8 Delpech MA, Hillairet M. Accidents found amongst workers: employees making chromates. Ann d'Hygiene Publique et de Medicine Legal 1876;193-233.

9 Card WI. A case of asthma sensitivity to chromates. Lancet 1935;229:1348-9.

10 Dahl R, Mikkelsen HB. Bronchial asthma and chromium allergy precipitated by steel welding. Ugeskr Laeger 1982; allergy precipit

11 Olaguibel JM, Basomba A. Occupational asthma induced by chromium salts. Allergol Immunopathol 1989;17:173-6.

12 Bergmann A. On a case of occupational asthma with allergy to a chemical substance. Schweiz Med Wochenschr 1934; 63:987-9.

13 Williams CD. Asthma related to chromium compounds. North Carolina Med f 1969;30:482-91.

14 Novey HS, Habib M, Wells ID. Asthma and IgE antibodies induced by chromium and nickel salts. $\mathcal{F}$ Allergy Clin Immunol 1983;72:407-12.
15 Keskinen H, Kalliomäki P-L, Alanko K. Occupational asthma due to stainless steel welding fumes. Clin Allergy 1980;10:151-9.

16 Ballal SG. Respiratory symptoms and occupational bronchitis in chromite ore miners, Sudan. $f$ Trop Med Hyg 1986;89:223-8.

17 McConnell LH, Fink JN, Schlueter DP, Schmidt MG Asthma caused by nickel sensitivity. Ann Intern Med 1973 78:888-90.

18 Block JT, Young $\mathrm{M}$. Asthma induced by nickel. $f A M A$ 1982;247:1600-2.

19 Malo J, Cartier A, Doepner M, Nieboer E, Evans S, Doovich J. Occupational asthma caused by nickel sulphate. Clin Allergy 1982;69:55-9.

20 Anderson SD, Schoeffel RE, Finney M. Evaluation of ultrasonically nebulised solutions for provocation testing in patients with asthma. Thorax 1983;38:284-91.

21 Balmes JR, Fine JM, Christian D, Gordon T, Sheppard D. Acidity potentiates bronchoconstriction induced by hypoosmolar aerosols. Am Rev Respir Dis 1988;138:35-9.

22 Magyar P, Dervaderics M, Toth A. Bronchial challenge with hypertonic $\mathrm{KCl}$ solution in the diagnosis of bronchial asthma. A comparison with the challenge performed by inhalation of distilled water. Schweiz Med Wochenschr 1984 114:910-3.

23 Malo J, Cartier A, Gagnon G, Evans S, Dolovich J. Isolated late asthmatic reaction due to nickel sulphate without antibodies to nickel. Clin Allergy 1985;15:95-9.

24 Dolovich J, Evans SL, Nieboer. Occupational asthma from nickel sensitivity: 1 . Human serum albumin in the antinenic determinant. Br f Ind Med 1984;41:51-5.

25 Shirakawa T, Kusaka Y, Fujimura N, Kato M, Heki S, Morimoto K. Hard metal asthma: cross immunological and respiratory reactivity between cobalt and nickel? and respiratory reactivity 